\title{
Study of impact of anemia on pregnancy
}

\author{
Shradha S. Maka ${ }^{1 *}$, Sangamesh B. Tondare ${ }^{2}$, Mahesh B. Tondare ${ }^{3}$
}

\author{
${ }^{1}$ Department of Obstetrics and Gynecology, MRMC, Kalaburagi, Karnataka, India \\ ${ }^{2}$ Department of General Surgery, GIMS, Kalaburagi, Karnataka, India \\ ${ }^{3}$ Department of Community Medicine, BRIMS, Bidar, Karnataka, India
}

Received: 13 September 2017

Accepted: 09 October 2017

\author{
*Correspondence: \\ Dr. Shradha S. Maka, \\ E-mail: shradhasmaka@gmail.com
}

Copyright: (c) the author(s), publisher and licensee Medip Academy. This is an open-access article distributed under the terms of the Creative Commons Attribution Non-Commercial License, which permits unrestricted non-commercial use, distribution, and reproduction in any medium, provided the original work is properly cited.

\begin{abstract}
Background: Anemia during pregnancy is highly prevalent in developing countries like India. Mostly is nutritional, of which iron deficiency anemia is predominant. Pregnancy is a state of hemodilution, also there is increased requirement of iron and folic acid during pregnancy. The incidence varies with socioeconomic status, literacy. Anemia has adverse outcome on both mother and fetal health. Poor fetal outcome like increase in preterm deliveries, increase in intrauterine growth restriction, increase in NICU admission, intrauterine death is seen. Maternal complications increase with anemia. This study aims to study the prevalence, type of anemia and its effect on mother and fetus. Objective of present study were to investigate the type and degree of anemia and to study the maternal and perinatal outcome.

Methods: This study was done in department of obstetrics and gynecology in M. R. Medical college kalaburagi for 1 year. Study was conducted on 100 pregnant women. Haemoglobin estimation was done for all woman in $3^{\text {rd }}$ trimester. Severity of anemia was detected by ICMR (Indian Council of Medical Research) classification. Depending on degree and type of anemia all were treated and followed up for maternal and perinatal outcome.

Results: The incidence of mild, moderate, severe anemia were $28 \%, 54 \%, 18 \%$ respectively. Most of the anemic woman belonged to low socioeceonomic status $84 \% .16 \%$ had maternal complications. Poor perinatal outcome was seen in unbooked and referred cases.

Conclusions: Anemia continues to be a major problem in developing countries with poor maternal and neonatal outcome. Early diagnosis and treatment can improve both maternal and neonatal outcome.
\end{abstract}

Keywords: Anemia, Maternal outcome, Neonatal outcome, Pregnancy

\section{INTRODUCTION}

Anemia is one of the most important public health problem not only in India but also in most south east Asian countries. About 16-40\% maternal deaths occur due to anemia. Anemia also increase maternal morbidity and mortality. Pregnancy increases the requirement of various health nutrients, iron and folic acid. Hemodilution during pregnancy aggravates anemia.

Along with physiological causes, social causes like early marriage, teenage pregnancy, decrease spacing between pregnancy, poor nutritional supplementation also contribute to anemia. Incidence of anemia during pregnancy in india ranges between $65-75 \% .^{1}$

In India NNACP was initiated to provide free iron and folic acid supplementation to pregnant woman from second trimester to three months postpartum. ICMR data shows $84.2 \%$ anemia prevalence in rural pregnant women, of which $13.1 \%$ were severe anemia. ${ }^{2}$

In India $26.3 \%$ of pregnant woman have institutional deliveries, have minimal number of visits to nearest 
antenatal clinic. ${ }^{3}$ If anemia detected earlier the hazards of parentral iron therapy and blood transfusion can be avoided. $^{4}$

Anemia the most preventable cause of maternal mortality should be eradicated from the female population in the coming years, that will ensure better maternal and perinatal health. Hence need for this study is to know the complications and to counsel women to prevent further obstetrical complications. Objective of present study were to investigate the type and degree of anemia and to study the maternal and perinatal outcome.

\section{METHODS}

This study was conducted in the Department of Obstetrics and Gynecology, M. R. Medical College Kalaburagi, Karnataka, India for 1 year, from July 2015- 2016. A prospective randomized study was conducted on pregnant women in 3rd trimester attending OPD as well as IPD of OBG Department of M. R. Medical College Kalaburagi. Sample size was 100 antenatal cases attending OPD and IPD.

\section{Inclusion criteria}

- All women attending OPD and IPD in third trimester with haemoglobin of $<10.9 \mathrm{gm} / \mathrm{dl}$.

\section{Exclusion criteria}

- All women whose haemoglobin was more than $11 \mathrm{gm} / \mathrm{dl}$.

- $\quad$ Patients with First and second trimester pregnancy were not included.

All the patients were studied in detail regarding age, literacy, socio eceonomic status, parity, interval between pregnancy, menstrual history, any significant past history. General physical examination, systemic examination, obstetric examination was done. Data was collected during their visit in $3^{\text {rd }}$ trimester.

Following investigations were done

- Haemoglobin estimation- by Sahli's method.

- Complete blood picture.

- Blood group and Rh typing

- Peripheral smear- the type of anemia was studied by peripheral smear examination.

- Obstetric scan.

Anemia was classified according to Indian council of Medical Research criteria (ICMR).

- $\quad$ Mild anemia-10-10.9gm/dl

- Moderate anemia-7.1-10gm/dl

- Severe anemia- $<7 \mathrm{gm} / \mathrm{dl}$
According to degree of anemia all the subjects were treated with either oral or intravenous iron or blood transfusion and followed up during antepartum, intrapartum and postpartum period. Mean and Standard deviation was used.

\section{RESULTS}

Most common age group was 19-24 years (47\%), followed by 25-29 years (34\%). Many of the cases belonged to low socioeconomic status (84\%). $63 \%$ of the cases were multigravida, $37 \%$ were primigravida.

Table 1: Distribution of cases according to age.

\begin{tabular}{|lll|}
\hline Age group in years & No. of cases & Percentage \\
\hline$<19$ & 11 & 11 \\
\hline $19-24$ & 47 & 47 \\
\hline $25-29$ & 34 & 34 \\
\hline$>30$ & 8 & 8 \\
\hline Total & 100 & 100 \\
\hline
\end{tabular}

Table 2: Distribution of cases according to symptoms.

\begin{tabular}{|lll|}
\hline Symptoms & No. of cases & Percentage \\
\hline Asymptomatic & 19 & 19 \\
\hline Fatigability & 77 & 77 \\
\hline Pedal oedema & 62 & 62 \\
\hline Dyspnoea/palpitation & 25 & 25 \\
\hline Headache & 12 & 12 \\
\hline Giddiness & 1 & 1 \\
\hline Loss of appetite & 20 & 20 \\
\hline
\end{tabular}

$19 \%$ were asymptomatic. Majority of women presented with fatigability (77\%) and pedal oedema (62\%), dyspnoea was seen in 25 cases, 12 cases presented with headache, giddiness in $1 \%$.

Table 3: Distribution of cases according to severity of anemia.

\begin{tabular}{|lll|}
\hline Severity & No. of cases $(\mathbf{n = 1 0 0})$ & Percentage \\
\hline Mild & 28 & 28 \\
\hline Moderate & 54 & 54 \\
Severe & 18 & 18 \\
\hline
\end{tabular}

Most of the women had moderate anemia (54\%), 28\% presented with mild anemia, $18 \%$ had severe anemia. Severity of anemia was classified as ICMR classification.

Table 4: Distribution of cases according to peripheral smear study.

\begin{tabular}{lll} 
Peripheral smear & No of cases $(n=100)$ & Percentage \\
Dimorphic & 18 & 18 \\
$\begin{array}{l}\text { Microcytic } \\
\text { hypochromic }\end{array}$ & 82 & 82 \\
\hline
\end{tabular}


Peripheral smear study showed microcytic hypochromic anemia in majority of cases $(82 \%)$, dimorphic anemia on peripheral smear study was seen in $18 \%$.

Table 5: Distribution of cases according to treatment.

\begin{tabular}{|lll|}
\hline Treatment & No. of cases & Percentage \\
\hline Oral iron & 91 & 91 \\
\hline Parentral iron & 52 & 52 \\
\hline Blood transfusion & 18 & 18 \\
\hline
\end{tabular}

Oral iron was given in $91 \% .52 \%$ of the cases were given parentral iron. Blood transfusion was done in $18 \%$ cases. Among the blood transfused patients, all the patients were transfused packed cell.

Table 6: Distribution of cases according to maternal complications.

\begin{tabular}{|ll|l|}
\hline Maternal complications & No. of cases & Percentage \\
\hline Absent & 84 & 84 \\
\hline Present & 16 & 16 \\
\hline PPH & 4 & 4 \\
\hline Sepsis & 2 & 2 \\
\hline Postpartum fever & 9 & 9 \\
\hline Congestive cardiac failure & 1 & 1 \\
\hline Total & 100 & 100 \\
\hline
\end{tabular}

$84 \%$ had no complications. Maternal complication was seen in 16 cases, of which postpartum fever was most common, seen in 9 cases, followed by PPH in 4 cases, sepsis in 2 cases and congestive cardiac failure in $1 \%$.

Table 7: Distribution of cases according to fetal outcome.

\begin{tabular}{|lll|}
\hline Fetal outcome & & No. of cases \\
\hline Preterm & Yes & 20 \\
\hline & No & 80 \\
\hline IUGR & Yes & 28 \\
\hline & No & 72 \\
\hline NICU & Yes & 25 \\
\hline & No & 75 \\
\hline IUD & Yes & 3 \\
\hline & No & 97 \\
\hline
\end{tabular}

$20 \%$ of the women had preterm delivery. $28 \%$ of the babies were IUGR, NICU admission was seen in $25 \%$ cases. Intrauterine death was seen in 3 cases.

\section{DISCUSSION}

In the present study, $28 \%$ mild, $54 \%$ moderate and $18 \%$ were severely anemic. Majority of the anemia cases belonged to age group of 20-24 years (47\%). This was comparable to Alli R et al. ${ }^{5}$ Low socioeconomic status predisposes to anemia, poor nutrition being the leading cause of anemia. In the present study, $82 \%$ belonged to low socioeconomic group while $100 \%$ of women of the study Alli R et al belonged to low socioenomic status. In Rangnekar et al $67 \%$ of women belonged to low socioeconomic group. ${ }^{6}$ In the present study $53 \%$ were booked, $30 \%$ were unbooked and $18 \%$ were referred cases. $74 \%$ had severe anemia in unbooked and referred cases, this was comparable with Awasthi A et al $(83.5 \%)^{7}$

In the present $63 \%$ were multigravida, comparable with Awasthi A et al (65.5\%). ${ }^{7}$ In the present study spacing between pregnancy $<2$ years was $61 \%$ and $>2$ years is $39 \%$, comparable to Khandait DW et al, $55.9 \%$ and $44.1 \%$ respectively. ${ }^{8}$ In the present study microcytic hypochromic anemia was most common (82\%) followed by dimorphic anemia (18\%). Which is comparable to Awasthi A et al (66.5\%). ${ }^{7}$ In the present study $91 \%$ required oral iron, $52 \%$ required parentral iron and $18 \%$ blood transfusion. The requirement of blood transfusion was more in referred and unbooked cases. Preterm deliveries $20 \%$ and IUD $3 \%$ were comparable with study of Sarin AR, who observed that $31.2 \%$ women had preterm deliveries. ${ }^{9}$ Maternal complications like postpartum febrile illness $(9 \%)$, postpartum haemorrhage (4\%), sepsis (2\%), and congestive cardiac failure (1\%) was seen which was comparable to Awasthi A et al postpartum febrile illness $(14.1 \%){ }^{7} \mathrm{PPH}(7.5 \%)$ and puerperal sepsis $(3.5 \%)$. Fetal outcome in the form of preterm (20\%). IUGR (28\%), NICU Admission (25\%) and IUD (3\%) were seen which was comparable to to Awasthi A et al preterm (9.5\%), IUGR (37.5\%), IUD $(8 \%)$ and also with Rangnekar et al $(73 \%, 4 \%, 16 \%$ respectively). ${ }^{6,7}$ Incidence of low birth weight babies in the present study was $46 \%$ which was comparable to Khalida $\mathrm{H}$ et al. ${ }^{10}$

\section{CONCLUSION}

Anemia is the commonest medical disorder in pregnancy and is a very common problem in developing countries. It constitutes significantly to maternal morbidity and mortality. About $60-80 \%$ of pregnant woman have anemia and it contributes to $40 \%$ of maternal death. It also contributes to indirect death in the form of PPH, infection, cardiac failure. Anemia is also responsible for poor fetal outcome in the form of spontaneous abortion, preterm deliveries, low birth weight and intra uterine growth restriction. Among various causes of anemia, $90 \%$ are nutritional in origin, iron deficiency is the commonest.

Therefore, efforts should be done not only to correct anemia but also to prevent. Attention should be paid to menstrual problems, this is possible with better awareness and education of females in society. Delivery of anemic patients should be preferably done in a institute with ICU and blood bank facility.

Funding: No funding sources Conflict of interest: None declared 
Ethical approval: The study was approved by the Institutional Ethics Committee

\section{REFERENCES}

1. De Mayer EM, Tegman A. Prevalance of anemia in the World. World Health Organ Qlty. 1998;38:30216.

2. Indian Council of Medical Research. Evaluation of the National Nutritional Anemia Prophylaxis Programme. An ICMR Task Force Study. New Delhi ICMR; 1989.

3. SRS Sample registration system RGI, New Delhi. Maternal Mortality in India: 1997-2003: Trends, causes and Risk factors. Available at www.health.mp.gov.in/Maternal_Mortality_in_India _1997-2003.

4. Bhatt RV. Management of Pregnancy anaemia: Obstetrician's dilemma. J Obstet Gynecol India. 1998 Dec;48(6):96-100.

5. Alli R, Satyanarayana M. Anemia complicating pregnancy. J Obstet Gynecol India. 1985;35(2):3358.
6. Rangnekar AG, Rashmi D. Fetal outcome in pregnancy anemia. J Obstet Gynecol India. 1993 April;43(2):172-6.

7. Awasthi A, Thakur R, Dave A. Maternal and perinatal outcome in cases of Moderate and severe anemia. J Obstet Gynecol India. 2001 Dec;51(6):6265.

8. Khandait DW, Ambadikar NN, Zodpey PS. Risk factors for anemia in Pregnancy. J Obstet Gynecol India. 2001 Jan-Feb;51(1):42-44.

9. Sarin AR. Severe anemia of Pregnancy: Recent experience. Int J Gynecol Obstet India. 1997 July;1(1):39-44.

10. Khalida H, Shah GN, Farooq F. Some obstetric and fetal correlations in association with anemia in pregnancy. Indian J Maternal Child Health. 1997 April-June;8(2):48-50.

Cite this article as: Maka SS, Tondare SB, Tondare MB. Study of impact of anemia on pregnancy. Int $\mathbf{J}$ Reprod Contracept Obstet Gynecol 2017;6:4847-50. 